\title{
Knowledge, Awareness, and Perception on Child Sex Tourism among the Stakeholders in Bohol, Philippines
}

\author{
RAINELDA BITUIN F. CALIMBAYAN \\ rbfcalimbayan@gmail.com \\ http://orcid.org/0000-0001-5031-1534 \\ JICA CESZARAINE O. PACATANG \\ jicaceszaraine@gmail.com \\ http://orcid.org/0000-0002-0349-1031
}

\section{ABSTRACT}

Child sex tourism (or CST) refers to child sexual abuse wherein perpetrators are identified as tourists in the place where the child comes from. The study sought to determine the level of knowledge, awareness and perception among the stakeholders in the province of Bohol on child sex tourism. Utilizing a quantitative method approach with the aid of a survey questionnaire, the study involved 316 stakeholders from the Local Government Unit (LGU), Philippine National Police (PNP), and resort owners and employees. The study revealed that the stakeholders were extremely knowledgeable, moderately aware, and moderately agree on CST in their respective communities. Using the analysis of Paired Sample T-Test, it revealed out that there was a significant correlation among the variables on the level of knowledge, awareness, and perception on CST as perceived by the stakeholders. The findings of this study encourage reinforcement of evidence-based advocacy and continued lobbying to improve and implement child protection policies in the province. 
Keywords: Child sex tourism, CST, awareness, knowledge, perception, prostitution, t-test, quantitative method, Bohol, Philippines

\section{INTRODUCTION}

The tourism industry has seen accelerated growth in recent decades, making it one of the fastest growing industries in the world. According to the Word Tourism Organization (UNWTO) Tourism Barometer, tourism generated approximately 6 percent of the world's trade, creating revenue of 1.3 billion USD with a total of 5 percent growth of international arrivals in 2013. Moreover, tourism generated 1 of every 12 jobs, making it an important player in the employment sector (UNWTO World Tourism Barometer, 2014). The growth of international arrivals in the Least Developed Countries (LDC's) has seen a remarkable growth from six million in 2000 to over 17 million in 2010.

The tourism industry has become an important contributor to the LDC's economic growth, and UNTWO Executive Director, Márcio Favilla has stated that tourism is one of the few economic sectors through which LDCs have managed to increase their participation in the global economy" (UNTWO, 2011). Despite the positive outcome of the tourism context, it also brings alarming consequences, for instance, child sex tourism. The sexual exploitation of minors by international tourists is a humanitarian crisis carried out on a global scale with seemingly little to no repercussions for the criminal perpetrators. According to End Child Prostitution in Asian Tourism (ECPAT), an international child advocacy organization based in Bangkok, child prostitution in poorer countries is a culturally embedded problem that is significantly exacerbated by the influx foreign tourists (Andrews, 2004).

Child prostitution is an old, global and complex phenomenon, which deprives children of their childhood, human rights and dignity (Lau, 2008). Globally, an estimated one million children are forced into prostitution every year, and the total number of prostituted children could reach as high as 10 million (Ryan, 2000). The sexual exploitation of children for economic purposes is among the worst forms of human rights abuses (Hernandez, Truyol, \& Larson, 2005).

Economically promising as it may be, the province is faced with a phenomenon that involves exploitation among children and women. In fact, End Child Prostitution Child Pornography and Trafficking in Children for Sexual Purposes (ECPAT) has identified towns and communities in 
the province wherein child sex tourism, and commercial sex exploitation of children are rampant. The said international organization has been promoting advocacies on ending child prostitution by conducting seminars among stakeholders in the province to disseminate information on what is child sex tourism (CST) and commercial sexual exploitation of children (CSEC).

The ECPAT deliberately crisscrossed the entire province of Bohol to investigate such cases. However, there is no proper coordination with the local government as to how it should be properly handled. It has been reported that international tourists are predicted to reach 1.8 billion by 2030 (UNTWO, 2011). This increase raises the risk of children falling victim to child sex tourism. Children who are at the most risk of CST are either those who are already victims of abuse or who are extremely poor.

In line with the interdisciplinary nature of public administration, the results of this study represent a fundamental step in identifying areas for future inquiry and research, which is particularly important given the role of community attitudes in shaping behavior, behavioral change, and government policy responses and actions. Such will also provide baseline data on the extent of awareness and knowledge on child sex tourism involving the stakeholders specifically the local government unit, establishment owners, and employees. The level of knowledge, awareness, and perception among the stakeholders will be the basis for the development of a strategic framework that aims to eradicate child sex tourism cases in the province. Gaps in the knowledge, awareness, and perception will be analyzed to determine the needs to be addressed and to be given emphasis for further planning and implementations of programs.

Anderson (2005) theorized that the Outcomes Framework provides the basis for identification of activities or interventions that will lead to the outcomes previously identified as conditions for achieving long-term goals. Through this approach, the precise link between activities and the achievement of the long-term goals are more fully understood. This leads to better planning since activities are linked to a detailed understanding of how change occurs. It also enables better evaluation, as it is becomes possible to measure progress towards the achievement of longer-term goals that go beyond the identification of program outputs. The theory is appropriate for the study as it aims to construct and create a strategic framework that will serve as guidelines and basis to address the problem of child sex tourism. 
Child sex tourism is a global problem that affects the majority of nations and remains one of the most profitable forms of global organized crime. It occurs transnational and within domestic borders and adversely affects children's health, development, and wellbeing. Sadly, its incidence has been increased by the recent global recession (ECPAT International, 2009). Brazil has 250,000-500,000 children in the sex trade and the number of children involved in Colombia, Russia, and Benin is growing rapidly. Even the United States has not been spared this horrific situation as up to 300,000 prostituted children may be found inside its borders (Klain, 1999). In the past two decades, Asia has rapidly become the center of child prostitution with an estimated 60,000 child prostitutes in the Philippines, 400,000 in India, and 800,000 in Thailand (Sachs, 1994). There is usually no ample support and protection for the victims due to insufficient governmental services for the victims of sexual exploitation.

Child-sex tourists generally come from more economically-developed countries. These tourists then travel to countries that are experiencing widespread poverty but have a well-developed and highly commercialized sex industry (Klain, 1999). ECPAT compiled data from 1991 to 1996 on 240 foreigners who sexually abused children in Asia during the previous seven years and were arrested, imprisoned, deported, or escaped without penalty. From this group, 24-25 percent were from the United States, 16 percent were German, 13 percent were British, 12 percent were Australian, and 7 percent each were French and Japanese.

Countries in Asia like Thailand, Cambodia, and the Philippines have been reported to be destinations for tourists who wish to have sex with children as children living in poverty tend to be more vulnerable to sexual exploitation. Employment in the tourism and catering industries is often an entry point to commercial sexual activity for children and adolescents (Mahler, 1997). In these countries, there is a need for more involvement from local stakeholders, including local tourism boards, tourist police, the chamber of commerce and local government bodies responsible for regulating tourism development. Being able to raise awareness about the sexual exploitation of children in travel in tourism is very important.

The Philippines is highly affected by all forms of commercial sexual exploitation of children, which seem to be closely linked and greatly impact one another. A study conducted by Nurmi (2014) that focuses on tourist awareness on child sex tourism, concluded that the term "child sex tourism" is generally well recognized. Despite the growing awareness 
of the commercial sexual exploitation of children and human trafficking, child sex tourism continues to be a lucrative industry. Even before the recent global financial crisis, the sex industry, including child sex tourism, has been a very significant contributor to the gross domestic product (GDP) in some countries.

A lack of understanding of children's rights within Filipino society is a strong contributing factor in the commercial sexual exploitation of children. Trinidad (2005) stated that children are often considered 'parental property' and are taught to be submissive and obedient to adults at all times. This mindset often compromises their ability to defend themselves when being approached for exploitative, sexual activities. Parents, children, and authorities often fail to grasp the full implications and the extent of the impact that such activities may have on a child's life. UNICEF (2005) reports that families seem reluctant to bring child sexual abuse charges for fear that it might tarnish the image of the family and cause them to be ostracized. Thus, an urgent need is seen to make parents and children more sensitive to the issue (Trinidad, 2005).

The study sought to explore knowledge, awareness, and perception of child sex tourism among the local stakeholders in the province of Bohol.

Specifically, the study aimed to:

1. To describe the level of knowledge on child sex tourism among the respondents;

2. To describe the level of awareness on child sex tourism among the respondents;

3. To describe the level of perception on child sex tourism among the respondents; and

4. To determine if there is a significant degree of correlation between the level of knowledge, awareness, and perception of child sex tourism as perceived by the stakeholders.

\section{METHODOLOGY}

The study employed a quantitative design. Mayo (2014) describes the different methods vary from the sample size, purpose, settings and how the data is being analyzed. For quantitative approach, one shot survey was conducted, and respondents were chosen utilizing a random sampling 
procedure. Listings of institutions and employees were the bases of random selection from the on-going records of the targeted respondents.

Marshall and Rossman (2014) assert that one of the most important steps in the research is choosing the right sampling technique, as this will ideally lead to the right study sample. The study involved 30 percent of the total population of the targeted respondents. Purposive and stratified sampling were used in selecting the specific stakeholders as it targets respondents from the Tourism, Municipal Social, Welfare and Development, Administrative Office, community officials from the Local Government Unit (LGU), the Philippine National Police, resorts and hotels employees. Equal distribution among respondents was properly observed to come up with normality value on the data sets

The research focused a provincial scope focusing Bohol wherein six out of eight identified municipalities were child sex tourism (CST) hotspots according to ECPAT International. Among the six out of eight identified municipalities, it further identified specific communities wherein child sex tourism (CST) is currently rampant. There were a total of 23 communities involved in the study.

Table 1. Locale of the study

\begin{tabular}{|c|l|}
\hline Municipality & \multicolumn{1}{|c|}{$\begin{array}{c}\text { Communities } \\
\text { (Barangay) }\end{array}$} \\
\hline Anda & Poblacion \\
\hline \multirow{4}{*}{ Jagna } & Canjulao \\
\cline { 2 - 2 } & Canupao \\
\cline { 2 - 3 } & Looc \\
\cline { 2 - 3 } & Pagina \\
\hline \multirow{4}{*}{ Panglao } & Tejero \\
\hline \multirow{4}{*}{ Tagbilaran } & Doljo \\
\hline \multirow{3}{*}{} & Tawala \\
\hline & Cogon \\
\hline & Mansasa \\
\hline & Poblacion I \\
\hline & Poblacion II \\
\hline & San Isidro \\
\hline
\end{tabular}




\begin{tabular}{|c|c|}
\hline \multirow{4}{*}{ Tubigon } & Cahayag \\
\hline & Macaas \\
\hline & Poblacion \\
\hline & Pooc Occidental \\
\hline \multirow{6}{*}{ Ubay } & Calanggaman \\
\hline & Casate \\
\hline & Fatima \\
\hline & Poblacion \\
\hline & San Vicente \\
\hline & Tapal \\
\hline
\end{tabular}

Local stakeholders specifically from the Local Government Unit (LGU), Philippine National Police (PNP) and resorts and hotel owners from the targeted municipalities were the respondents in this study.

Table 2. Distribution of the stakeholders per sectors

\begin{tabular}{|l|c|c|}
\hline \multicolumn{1}{|c|}{ SECTORS } & $\boldsymbol{f}$ & $\%$ \\
\hline $\begin{array}{l}\text { Local Government Unit } \\
\text { *(DSWD, Tourism Office, Administration Office \& } \\
\text { Barangay Officials) }\end{array}$ & 125 & 39.56 \\
\hline Philippine National Police & 66 & 20.88 \\
\hline Resorts/Hotels Owners \& Staff & 125 & 39.56 \\
\hline \multicolumn{1}{|c|}{ TOTAL } & $\mathbf{3 1 6}$ & $\mathbf{1 0 0 . 0 0}$ \\
\hline
\end{tabular}

The survey tool used to collect the quantitative data consisted of a self-constructed questionnaire. For the effectiveness of the questionnaire, a pilot test was conducted among 30 people with similar socio-demographic profiles similar to the respondents, and necessary corrections were made before the final conduct of the survey. The first part contains the respondents' socio-demographic characteristics such as age, sex, civil status, and occupation, and work Institution, length of service in work, highest educational attainment, and organizational affiliation. The second part comprised of information to verify the knowledge on child sex tourism. The third part covered the questions to attest to the level of awareness on child sex tourism. Lastly, the fourth part of the questionnaire tackled on the level of perception of the stakeholders on the said topic. 
Before the collection of data, the outline of the proposed study was subjected to research ethics review as it addresses the ethical considerations of the topic that involves children and women. Upon approval, the certification from the University Research Center, a permission to administer the survey and interviews from the Local Government Unit (LGU) and the chosen establishments were sent to ensure full support and cooperation from the targeted respondents. Endorsement from the office of Education Center, Provincial Tourism Office and the Governor's Office and the Mayor's Office from the LGU was provided. Then, the researchers conducted the data gathering in the said municipalities and communities.

The data was coded and encoded in Microsoft Excel and were later on imported and analyzed using Statistical Package for Social Science (SPSS) Version 20. Descriptive statistics such as percentages, means and standard deviations were used to describe the respondents' sociodemographic profile, knowledge, level of awareness and level of perception. For the relationship between variables specifically on the stakeholders' level of knowledge, awareness and perception Paired Sample T-Test was used for the statistical treatment.

\section{FINDINGS}

\section{Stakeholders' Level of Knowledge on Child Sex Tourism}

The level of knowledge among the stakeholders on child sex tourism has been grouped based on grade point by calculating the total score out of the seventeen items on knowledge questions. The level of knowledge was categorized based on scaling and rated as extreme, moderate, slight and low. The questions tackled child sex tourism, laws against any forms of child abuse and child's rights.

Table 3. Scoring category on the stakeholders' level of knowledge on Child Sex Tourism

\begin{tabular}{|c|c|}
\hline Scoring Category & Level of Knowledge \\
\hline $100-75$ & Extreme \\
\hline $74-50$ & Moderate \\
\hline $49-25$ & Slight \\
\hline $24-0$ & Low \\
\hline
\end{tabular}


Table 4. Stakeholders' level of knowledge on Child Sex Tourism

\begin{tabular}{|c|c|c|}
\hline Level of Knowledge & $f$ & $\%$ \\
\hline Extremely Knowledgeable & 294 & 93.03 \\
\hline Moderately Knowledgeable & 17 & 5.38 \\
\hline Slightly Knowledgeable & 4 & 1.27 \\
\hline Less Knowledgeable & 1 & 0.32 \\
\hline
\end{tabular}

Out of 316 respondents, 283 (or 89.6\%) agreed with the statement "Child refers to a person aged below 18 years old," while the rest of them $(15.2 \%)$ did not. Meanwhile, the majority of them $(89.6 \%)$ believed that the statement on "Child sex tourism is tourism for the purpose of engaging in the prostitution of children that is commercially facilitated child sexual abuse" was true. However, a little over three-fourths $(80.4 \%)$ disagreed with the statement that "Girls are the only victims of child sex tourism" while almost one-fourth (19.6\%) stated that it was true. With regards to the statement on "Every child has the right to live peacefully away from bad influences," almost all (97.2\%) of the participants validated such claim. When asked about the child's right on "RA 7610 that refers to special protection against child abuse, exploitation, and discrimination," almost all of them (93.6\%) agreed with such statement.

Majority of the stakeholders (95.3\%) agreed with the statement that "RA 9262 refers to defining violence against women and their children, providing for protective measures for victims, prescribing penalties." On the statement on "RA 10175 refers to the Cybercrime Prevention Act of 2012," 93.4 percent answered in the affirmative. On the statement "Cyber exposure of children who are sexually assaulted is one example of child sex tourism," almost all of them (94.6\%) responded in the affirmative. Ninety-six percent agreed with the statement that "Child abuse refers to the maltreatment, whether habitual or not, of the child which includes sexual abuse." On the statement on "Child prostitution refers to children who for money, profit, or any other consideration or due to coercion or influence of any adult, syndicate or group, indulge in sexual intercourse or lascivious conduct, are deemed to be children exploited in prostitution and other sexual abuse," 95.9 percent were in agreement. 
For the statement on "Every child has the right to be cared for whenever their parents are not available or cannot sustain their needs", 97.2 percent of respondents were in agreement. Meanwhile, "RA 7610 refers to special protection against child abuse, exploitation, and discrimination", 93.4 percent of respondents agreed with the statement.

For the statement on "any person who shall hire, employ, use, persuade, induce or coerce a child a child to perform in obscene exhibitions and indecent shows, whether live or in video, or model in obscene publications or pornographic materials or to sell and distribute the said materials shall suffer the penalty of prison mayor in its medium period" almost all of the stakeholders (93.4\%) thought the item was true. Lastly, on the statement on "Child abuse refers to the maltreatment, whether habitual or not, of the child which includes sexual abuse," the majority (95.9\%) of the respondents were in agreement.

When asked about the statement that "Any person who shall hire, employ, use, persuade, induce or coerce a child a child to perform in indecent shows and obscene publications, whether live or in video, or model in pornographic materials or obscene publications or sell or distribute the said materials shall suffer the penalty of prison mayor in its medium period". Almost all of them $(93.4 \%)$, believed that the statement is correct.

On the other hand, for the statement on "Any person who shall keep or have in his company a minor 12 years or less who is at least ten years younger or more in any public or private place, hotel, motel, beer joint, discotheque, cabaret, pension house, sauna or massage parlor, beach. other tourist resorts or similar places shall bear the penalty of prison mayor in its maximum period and a fine of not less than fifty thousand pesos. This provision shall not apply to any person who is related within the fourth degree of consanguinity or affinity or any bond recognized by law, local custom, tradition or acts in the performance of a social, moral or legal duty" was believed to be true among 91.1 percent of the respondents.

On the item "Any person, owner, manager or one entrusted with the operation of any public or private place of accommodation, whether for occupancy, food, drink or otherwise, including residential places, who allows any person to take along with him to such places any minor herein described shall be meted a penalty of prison mayor in its medium period 
and a fine of not less than fifty thousand pesos, and the loss of the license to operate such a place or establishment", almost all of the stakeholders $(91.5 \%)$ answered in the affirmative. Finally, for the statement on "Any person who shall engage in trading and deal with children including the act of buying and selling of a child for money, or for any other consideration, or barter, shall bear the penalty of reclusion temporal to reclusion perpetual. The penalty will be imposed in its maximum period when the victim is less than 12 years of age" was claimed to be true among 92.4 percent of the respondents.

The majority of the respondents (93.03\%) are extremely knowledgeable in the context of child sex tourism. Only a minimal number $(5.38 \%)$ of the respondents showed moderate knowledge towards the topic proving that the stakeholders were already knowledgeable and had an idea about CST.

\section{Stakeholders' Level of Awareness on Child Sex Tourism}

Table 5. Stakeholders' level of awareness on Child Sex Tourism

\begin{tabular}{|l|l|l|l|l|l|}
\hline \multicolumn{1}{|c|}{ ITEMS } & N & Mean & $\begin{array}{c}\text { Std. } \\
\text { Deviation }\end{array}$ & Derived Value & Rank \\
\hline $\begin{array}{l}\text { Aware of what is child sex } \\
\text { tourism. }\end{array}$ & 316 & 3.35 & 0.84 & Fully Aware & 1 \\
\hline $\begin{array}{l}\text { Aware that I am liable and } \\
\text { responsible with my actions } \\
\text { towards child sex tourism. }\end{array}$ & 316 & 3.25 & 0.86 & Fully Aware & 2 \\
\hline $\begin{array}{l}\text { Aware that there are } \\
\text { certain authorities whom } \\
\text { I can report on child sex } \\
\text { tourism cases. }\end{array}$ & 316 & 3.24 & 0.84 & $\begin{array}{l}\text { Moderately } \\
\text { Aware }\end{array}$ & 3 \\
\hline $\begin{array}{l}\text { Aware that my community } \\
\text { has implementing policy on } \\
\text { child protection to address } \\
\text { child sex tourism. }\end{array}$ & 316 & 3.09 & 0.92 & $\begin{array}{l}\text { Moderately } \\
\text { Aware }\end{array}$ & 4 \\
\hline $\begin{array}{l}\text { Aware that child sex } \\
\text { tourism is happening in my } \\
\text { community. }\end{array}$ & 316 & 2.8 & 1.06 & $\begin{array}{l}\text { Moderately } \\
\text { Aware }\end{array}$ & 5 \\
\hline $\begin{array}{l}\text { Aware of who are the } \\
\text { victims of child sex tourism } \\
\text { in my community. }\end{array}$ & 316 & 2.53 & 1.11 & $\begin{array}{l}\text { Moderately } \\
\text { Aware }\end{array}$ & 6 \\
\hline
\end{tabular}




\begin{tabular}{|c|c|c|c|c|c|}
\hline ITEMS & N & Mean & $\begin{array}{c}\text { Std. } \\
\text { Deviation }\end{array}$ & Derived Value & Rank \\
\hline $\begin{array}{c}\text { Aware and can identify } \\
\text { offenders of child sex } \\
\text { tourism in my community. }\end{array}$ & 316 & 2.32 & 1.04 & Slightly Aware & 7 \\
\hline Composite Mean & & 2.94 & & $\begin{array}{c}\text { Moderately } \\
\text { Aware }\end{array}$ & \\
\hline
\end{tabular}

Table 5 illustrates the level of awareness among the stakeholders involved in this study on child sex tourism in their respective communities and the province scope itself. It came out that the stakeholders were Fully Aware of "What is child sex tourism", with a mean of 3.35. Next in rank is the item on "Aware that I am liable and responsible for my actions towards child sex tourism" with a mean rate of 3.25 or Fully Aware. Third was the item on "Aware that there are certain authorities whom I can report on child sex tourism cases" with a mean rating of 3.24 which is Moderately Aware. Fourth is the item on "Aware that my community has an implementing policy on child protection to address child sex tourism" with a rate of 3.09.

With the bottom-ranked items, the stakeholders claimed that they were Slightly Aware of the item "Aware and can identify offenders of child sex tourism in my community" with a rating of 2.32 . On the other hand, the item on "Aware of who are the victims of child sex tourism in my community" ranked second to the last with a rate of 2.53 . Lastly, the item on "Aware that child sex tourism is happening in my community" ranked third from the last with a rating of 2.8 or Moderately Aware.

\section{Stakeholders' Level of Perception on Child Sex Tourism}

Table 6. Level of perception on Child Sex Tourism among the stakeholders

\begin{tabular}{|l|c|c|c|l|l|}
\hline \multicolumn{1}{|c|}{ ITEMS } & N & Mean & $\begin{array}{c}\text { Std. } \\
\text { Deviation }\end{array}$ & $\begin{array}{l}\text { Derived } \\
\text { Value }\end{array}$ & Rank \\
\hline $\begin{array}{l}\text { Sexually assaulted youth and } \\
\text { children often self- } \\
\text { disclose exploitation to social } \\
\text { workers or human health } \\
\text { professionals. }\end{array}$ & 316 & 3.35 & 0.81 & $\begin{array}{l}\text { Moderately } \\
\text { Agree }\end{array}$ & 1 \\
\hline
\end{tabular}




\begin{tabular}{|l|l|l|l|l|l|}
\hline \multicolumn{1}{|c|}{ ITEMS } & N & Mean & $\begin{array}{c}\text { Std. } \\
\text { Deviation }\end{array}$ & $\begin{array}{c}\text { Derived } \\
\text { Value }\end{array}$ & Rank \\
\hline $\begin{array}{l}\text { Children who are sexually } \\
\text { assaulted may still be under } \\
\text { the control of a pimp/trafficke, } \\
\text { even after they are returned to } \\
\text { foster care, family home, or are } \\
\text { rescued. }\end{array}$ & 316 & 3.29 & 1.02 & $\begin{array}{l}\text { Moderately } \\
\text { Agree }\end{array}$ & 2 \\
\hline $\begin{array}{l}\text { Outward symptoms of } \\
\text { depression or hostility may } \\
\text { present as difficult behavior to } \\
\text { assistance when working with a } \\
\text { possible victim. }\end{array}$ & 316 & 3.09 & 0.81 & $\begin{array}{l}\text { Moderately } \\
\text { Agree }\end{array}$ & 3.5 \\
\hline $\begin{array}{l}\text { Sexually exploited children } \\
\text { and youth often identify as } \\
\text { victims. }\end{array}$ & 316 & 3.09 & 0.78 & $\begin{array}{l}\text { Extremely } \\
\text { Agree }\end{array}$ & 3.5 \\
\hline $\begin{array}{l}\text { Prior sexual abuse is } \\
\text { commonly experienced among } \\
\text { commercially sexually exploited } \\
\text { children. }\end{array}$ & 316 & 3.05 & 0.80 & $\begin{array}{l}\text { Moderately } \\
\text { Agree }\end{array}$ & 5 \\
\hline $\begin{array}{l}\text { Exploited children typically } \\
\text { report their traffickers/pimps }\end{array}$ & 316 & 2.84 & 0.92 & $\begin{array}{l}\text { Moderately } \\
\text { Agree }\end{array}$ & 6 \\
\hline $\begin{array}{l}\text { Chronic runaway and } \\
\text { homeless youth are at } \\
\text { highest risk for exploitation. }\end{array}$ & 316 & 2.72 & 0.84 & $\begin{array}{l}\text { Extremely } \\
\text { Agree }\end{array}$ & 7 \\
\hline \multicolumn{1}{c|}{ Composite Mean } & 3.06 & $\begin{array}{l}\text { Moderately } \\
\text { Agree }\end{array}$ & \\
\hline
\end{tabular}

In this portion, the level of perception on random child sex tourism related statements were being scaled from the stakeholders depending on how they perceived the given statements. With a rating of 3.31, the item on "Sexually assaulted youth and children often self-disclose exploitation to social workers or human health professionals" ranked as the highest among all of the statements. This is closely followed by the item on "Children who are sexually assaulted may still be under the control of a pimp/trafficker, even after they are returned to foster care, family home, or are rescued" with a rating of 3.29. Third in rank is a tie between two items on "Outward symptoms of depression or hostility may present as difficult behavior to assistance when working with a possible victim" and "Sexually exploited children and youth often identify as victims" with a mean rating of 3.09 .

With regards to items ranked as the bottom three, the item on "Chronic runaway and homeless youth are at highest risk for exploitation" ranked as the lowest among the statements with a rating of 2.72 . While this is followed 
by the item on "Exploited children, typically report their traffickers/pimps" with a rating of 2.84, and lastly, the item on "Prior sexual abuse is commonly experienced among commercially sexually exploited children" which had a rating of 3.05 .

\section{Correlation among the variables on the Stakeholders' Knowledge, Awareness, and Perception on Child Sex Tourism}

Table 7. Paired sample T-test among the variables on the stakeholders' knowledge, awareness and perception on Child Sex Tourism

\begin{tabular}{|c|c|c|c|c|c|c|c|c|c|}
\hline & \multicolumn{5}{|c|}{ Paired Differences } & \multirow[b]{2}{*}{$t$} & \multirow[b]{2}{*}{ df } & \multirow[b]{2}{*}{ Sig. } & \multirow{4}{*}{ REMARKS } \\
\hline \multirow[t]{3}{*}{ VARIABLES } & Mean & Std. & Std. & & & & & & \\
\hline & & \multirow[t]{2}{*}{$\begin{array}{l}\text { Devi- } \\
\text { ation }\end{array}$} & \multirow[t]{2}{*}{$\begin{array}{l}\text { Error } \\
\text { Mean }\end{array}$} & \multicolumn{2}{|c|}{$\begin{array}{l}\text { Confidenc } \\
\text { Interval of the } \\
\text { Difference }\end{array}$} & & & (2-tailed) & \\
\hline & & & & Lower & Upper & & & & \\
\hline $\begin{array}{l}\text { Knowledge } \\
\text { \& Awareness }\end{array}$ & 0.77 & 0.80 & 0.04 & 0.68 & 0.86 & 17.05 & 315 & $\begin{array}{c}0.00 \\
0\end{array}$ & Significant \\
\hline $\begin{array}{l}\text { Knowledge } \\
\text { \& Perception }\end{array}$ & 0.65 & 0.74 & 0.041 & 0.57 & 0.73 & 15.62 & 315 & $\begin{array}{c}0.00 \\
0\end{array}$ & Significant \\
\hline $\begin{array}{l}\text { Awareness } \\
\text { \& Perception }\end{array}$ & -0.11 & 0.67 & 0.03 & -0.19 & -0.04 & -3.13 & 315 & $\begin{array}{c}0.00 \\
0\end{array}$ & Significant \\
\hline
\end{tabular}

To determine the correlation among variables, the study used paired sample test analysis.

Between knowledge and awareness, the computed $t$ value is 17.05 with a degree of freedom of 315 at the level of .005 . There is a significant difference between the two variables. This means that the level of knowledge was significantly related to the level of awareness on child sex tourism among the stakeholders.

With regards to the level of knowledge and perception, with a computed value of 15.62 and with the degree of freedom of 315 at the level of .005, the result came out with a notion that there was a significant correlation between the two variables.

The level of awareness and perception were also measured to determine if there is a significant degree of difference between the two variables. With a computed $t$ value of -3.133 with a degree of freedom of 315 at the level of .005 , it resulted in a significant degree of difference between the two variables. 
The result proves that there was an interplay between the level of knowledge, awareness, and perception of the stakeholders on child sex tourism in the province. All of the variables in this study affected each other. Also, the problem of child sex tourism in the province is widely known and the stakeholders are aware of its existence in their respective communities.

\section{CONCLUSION}

Basing from the data gathered and analyzed, the statement below are the conclusions of the study:

Level of knowledge on child sex tourism - Although there were a minimal number of stakeholders who were moderately, slightly, and less knowledgeable on child sex tourism, the majority of them were extremely knowledgeable on the basic information about child sex tourism.

Level of awareness on child sex tourism - The stakeholders were moderately aware of the context and identification of child sex tourism and their duties and responsibilities when child sex tourism occurs in their respective communities.

Level of perception on child sex tourism - The stakeholders moderately agreed on the random statements about child sex.

Correlation among Variables on Knowledge, Awareness, and Perception on child sex tourism - The knowledge, awareness, and perception of the stakeholders on child sex tourism interplayed with each other and it coincided with each of the variables.

\section{RECOMMENDATIONS}

Given the result that stakeholders had extreme knowledge on child sex tourism, the study outcomes provide the opportunity for the local government unit to penetrate the context on child sex tourism to the community by conducting widespread information dissemination that aims to provide educational orientation to the local residences especially the parents.

The local government unit should implement baseline study on the exis- 
tence of CST cases in their municipality. This will be used as a basis for enriching the level of awareness among the stakeholders and locals to prevent the problem from occurring and protect the children in their communities.

Results of the study recommend that every municipality should craft policies and ordinances that address child protection. Through this, sanctions and penalties should be reinforced to properly implement the rights of the child with regards to any forms of abuses.

The interplay between the knowledge, awareness, and perception of CST among the stakeholders suggests that the information, causes, effects, and identification of the CST reinforced through exposures and information dissemination to upgrade the overall orientation of the stakeholders and the locals most especially the parents to prevent and completely eradicate it from occurring in the community.

\section{REFERENCES}

Anderson, T. (2005). Distance learning-Social software's killer ap?. Retrieved from https://goo.gl/7azxpx, (accessed last 29 November 2015).

Andrews, S. K. (2004). US domestic prosecution of the American international sex tourist: Efforts to protect children from sexual exploitation. The Journal of Criminal Law and Criminology (1973-), 94(2), 415-454. Retrieved from https://goo.gl/Cg8XQ9, (accessed last 4 December 2015).

ECPAT International Reports, 2009. Retrieved from https://goo.gl/RswGo9, (accessed last 14 December 2015).

ECPAT Philippines, Child Sex Tourism in Cebu, 2004. Retrieved from https:// goo.gl/LT9u8z, (accessed last 14 December 2015).

Hernandez, Truyol, B. E., \& Larson, J. E. (2005). Sexual labor and human rights. Colum. Hum. Rts. L. Rev., 37, 391. Retrieved from https://goo.gl/ ehsLBM, (accessed last 15 December 2015). 
Klain, E. J. (1999). and the Law Prostitution of Children and Child-Sex Tourism: An Analysis of Domestic and International Responses. Retrieved from https://goo.gl/7FJWeh, (accessed last 17 January 2016).

Lau, C. (2008). Child prostitution in Thailand. Journal of Child Health Care,12(2), 144-155. Retrieved from https://goo.gl/CRenjx, (accessed last 14 December 2015).

Mahler, Karen. "Global concern for children's rights: The world congress against sexual exploitation." International Family Planning Perspectives (1997): 79-84. Retrieved from https://goo.gl/K7PbXX, (accessed last 4 February 2016).

Marshall, C., \& Rossman, G. B. (2014). Designing qualitative research. Sage publications. Retrieved from https://goo.gl/1Tu9eV, (accessed last 15 December 2015).

Mayo, E. (2014). The social problems of an industrial civilisation. Routledge. Retrieved from https://goo.gl/NzLiYU, (accessed last 14 December 2015).

Nurmi, S. L. (2014). Awareness of child sex tourism among young Finnish travellers. Retrieved from https://goo.gl/Dccx9i, (accessed last 15 December 2015).

Rafferty, Y. (2013). Child trafficking and commercial sexual exploitation: A review of promising prevention policies and programs. American journal of orthopsychiatry, 83(4), 559-575. Retrieved from https://goo. gl/yTrrm4, (accessed last 15 December 2015).

Ryan, C. (2000). Sex tourism: paradigms of confusion. Tourism and sex: Culture, commerce and coercion, 23-40. Retrieved from https:// goo.gl/XdQWqK, (accessed last 29 November 2015).

Sachs, A. (1994). The last commodity: child prostitution in the developing world. World Watch, 7(4), 24-30. Retrieved from https://goo.gl/fKMdGX, (accessed last 8 January 2016). 
Trinidad (2005). Policing Desire: Pornography, AIDS and the Media. A\&C Black.

UNICEF Report, 2005. Retrieved from https://goo.gl/1fT6Qa, (accessed last 15 December 2015).

UNWTO Annual Report 2011. Retrieved from https://goo.gl/jV1Gbr, (accessed last 15 December 2015).

UNWTO World Tourism Barometer. (2014). Retrieved from https://goo.gl/ RiKHbz, (accessed last 15 October 2015). 